Short Communication

\title{
ACUTE PHASE PROTEINS - AS INDICATORS OF CLAW DISEASES IN DAIRY CATTLE
}

\author{
Ksenija Ilievska1, Branko Atanasov ${ }^{2}$, Toni Dovenski², Ozren Smolac ${ }^{3}$, \\ Boris Stojanov ${ }^{4}$, Plamen Trojachanec ${ }^{1}$ \\ ${ }^{1}$ Department of Surgery, Orthopedics and Ophthalmology, Faculty of Veterinary Medicine, \\ Ss. Cyril and Methodiu University s, Skopje, R. Macedonia \\ ${ }^{2}$ Department of Reproduction, Faculty of Veterinary Medicine, \\ Ss. Cyril and Methodius University, Skopje, R. Macedonia \\ ${ }^{3}$ Department of Surgery, Orthopedics and Ophthalmology, \\ Faculty of Veterinary Medicine, University of Zagreb, Croatia \\ ${ }^{4}$ Veterinary Center, Strumica, R. Macedonia
}

Received 3 June 2018; Received in revised form 21 November 2018; Accepted 28 December 2018

\begin{abstract}
The serum concentration of certain acute phase proteins significantly increases during various pathological conditions in cattle. The aim of this study was to determine the influence of claw disorders etiology on the concentrations of two major acute phase proteins in dairy cattle: haptoglobin (Hp) and serum amyloid protein A (SAA). Fifty dairy cows with claw pathology were included. Fourteen clinically healthy heifers served as controls. The animals were subdivided in 5 groups according to the pathological findings on their claws: 1. Heel horn erosion (HE), 2. Acute laminitis (AL), 3. Sole ulcer (SU), 4. Digital dermatitis (DD) and 5. White line separation (WLS). Hp and SAA concentrations were measured in serum samples using commercial ELISA kits. Higher concentrations of both Hp and SAA were found in the AL and SU groups $(p<0.01)$ compared to the HE, DD and WLS and control groups. Dairy cows in the DD group had higher $(\mathrm{p}<0.05)$ Hp and SAA concentrations than the HE and WLS groups and the controls. The serum values between the HE, WLS and the control group did not differ significantly. The presented results indicate that the claw diseases are associated with a systemic acute phase response. Hp and SAA could be used as valuable biomarkers for early detection of claw diseases in dairy cows.
\end{abstract}

Key words: haptoglobin, serum amyloid A protein, dairy cattle, claw disease

\section{INTRODUCTION}

Claw disorders and lameness represent serious welfare problems for dairy cattle in terms of pain, discomfort and restricted behavior $(1,2)$. These problems also cause substantial financial losses due to reduced milk production, fertility, and body condition as well as the costs of veterinary treatments and extra labor $(3,4)$.

Corresponding author: Assist. Prof. Ksenija Ilievska, $\mathrm{PhD}$ E-mail address: kilievska@fvm.ukim.edu.mk

Present address: Department of Surgery, Orthopedics and

Ophthalmology, Faculty of Veterinary Medicine, Ss. Cyril and Methodius University, Skopje, R. Macedonia

Phone: +38923240776

Copyright: (C) 2019 Ilievska K. This is an open-access article published under the terms of the Creative Commons Attribution License which permits unrestricted use, distribution, and reproduction in any medium,

provided the original author and source are credited.

Competing Interests: The authors have declared that no competing interests exist.

Available Online First: 4 February 2019

Published on: 15 March 2019

https://doi.org/10.2478/macvetrev-2019-0011
In $95 \%$ of cases, lameness occurs in high-yield dairy cows especially during the first lactation $(4,5)$, while $90 \%$ of lameness is due to claw diseases (6).

According to the location of the pathological process, limb diseases can be divided in two groups: a) diseases of the digital and interdigital skin (digital and interdigital dermatitis, interdigital hyperplasia and interdigital phlegmon), and b) diseases of the corium and sensitive laminae (sole and white line haemorrhages, white line fissures, double soles, abscesses, sole ulcers and wall lesions such as sand cracks) (7). Inflammatory claw diseases such as sole ulcer, papilomatous digital dermatitis, interdigital necrobacilosis, septic pododermatitis and white line disease are the most common causes for lameness in dairy cattle $(4,8,9)$. Sole ulcer and white line disease are usually related to previous incidents of laminitis (4). 
Inflammation, infection, trauma, stress and other physiological processes induce an acute phase response (APR) in the organism in order to isolate and destroy the infective agents, to prevent further tissue/organ damage and to activate the reparative processes necessary for regaining normal function of the organism $(10,11)$. This response is non-specific by its origin and occurs regardless of the etiology (infective, traumatic, immunological, neoplastic or other) (12). During the APR, liver is being stimulated by the pro-inflammatory cytokines (TNF 2- $\alpha$, IL-1, IL-6 and INF- $\gamma$ ) to produce and release various specific proteins, defined as acute phase proteins (APP) $(13,14)$. Acute phase proteins are classified as positive and negative, depending on the concentration during the APR. The proteins exhibiting considerable concentration increase during APR are identified as positive APP (haptoglobin - Hp; serum amyloid protein A - SAA; C reactive protein - CRP; fibrinogen - Fb), while in contrast, the proteins exhibiting decreased concentration during APR are identified as negative APP (albumin, transferrin, etc.) (14). The serum concentration of these acute phase proteins after a single stimulus remains unchanged for at least 48 hours or longer (15).

Inflammatory processes or trauma in cattle induces considerable increase (10-100 times) of concentrations of serum $\mathrm{Hp}$ and SAA (16). In healthy animals, Hp and SAA are either absent or present in insignificant concentrations. In human medicine, detection of acute phase proteins is extensively used for monitoring of inflammation, infection or trauma progression (17). Acute phase proteins have proven to be sensitive markers for differential diagnosis between acute and chronic inflammatory conditions (mastitis, pneumonia, endometritis, bovine respiratory disease, traumatic reticuloperitonitis), postoperative monitoring of infectious complications, prognosis and efficacy of treatment as well as monitoring of dairy cow herd health $(15,18,19)$.

To our knowledge, only a few investigations have been published on the acute phase response in dairy cows with claw pathology. It is reported that claw diseases induce systemic acute phase response by elevation of certain acute phase proteins, as a result of tissue damage, pain and impaired homeostasis (20).

Considering the shortage of relevant investigations on APR in dairy cows associated with claw pathology, the aim of this study was to determine the influence of different claw diseases on APR and to investigate the possible use of Hp and SAA as a diagnostic tool for subclinical claw diseases in dairy cattle.

\section{MATERIAL AND METHODS}

The study was carried out on three commercial dairy farms with different housing systems. On the Farms 1 and 2, cows were housed in a tie stall system with hard, concrete floors and additional bedding material in order to create comfort while in Farm 3 cows were housed in a free stall system with deep, bedding material made of mixture of straw with high percentage of moisture and inadequate hygienic conditions. Cows were fed with Total mixed ration (corn silage, haylage, alfalfa silage, hay and concentrate) and milked by machine twice a day.

Corrective claw trimming was performed occasionally or when severe cases of lameness were detected. In order to exclude any pathological and physiological conditions that can affect the interpretation of the results, total of 425 animals were clinically examined using standard clinical examination procedures (temperature, respiratory rate, heart rate), followed by skin integrity check, California mastitis test, ultrasound gynecological examination as well as claw examination.

From the 425 animals submitted to triage, a total of 50 dairy cows with different claw pathology were selected for further investigation. All animals included in the survey were non-pregnant and free of systemic diseases.

Fourteen 12-15 months old, non-pregnant clinically sound heifers served as a control group. The remaining 361 dairy cows and heifers were excluded due to visible skin diseases and wounds, altered values of the triage, udder pathology, elevated somatic cell count, gravidity and infective reproductive disorders.

The experimental groups were divided into five groups according to claw pathology: 1. Heel erosions $(n=7) ; 2$. Acute laminitis $(n=13) ; 3$. Sole ulcer $(\mathrm{n}=10) ; 4$. Digital dermatitis (Mortelaro) $(n=15)$ and 5. White line separation $(n=5)($ Fig. 1-5).

Samples were collected from $v$. coccygea in evacuated tubes. Clear serum samples were obtained by centrifugation (10 min/2000 rpm) and frozen at $-20^{\circ} \mathrm{C}$ in sterile test tubes for further analysis. Hemolyzed samples were discarded (although light hemolysis is allowed by the manufacturer of the test).

Serum concentrations of both haptoglobin and serum amyloid A were determined by manual spectrophotometry Heidolph Titramax 1000, using commercial colorimetric kits (Phase Haptoglobin Assay and Multispecies SAA ELISA kit TP802, Tridelta Development Ltd), according to 


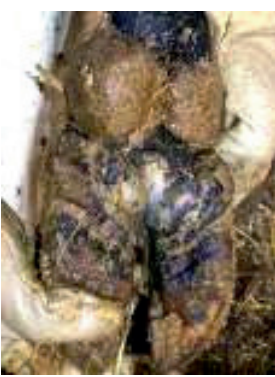

Figure 1.

Heel erosion

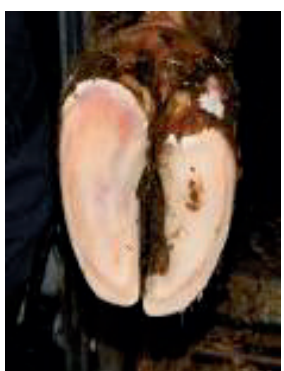

Figure 2.

Acute laminitis

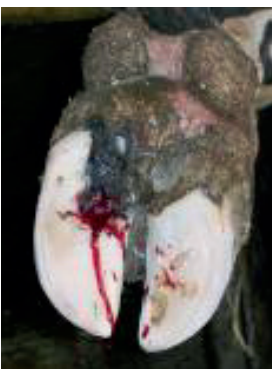

Figure 3.

Sole ulcer

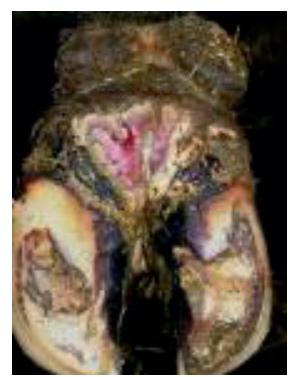

Figure 4.

Digital dermatitis

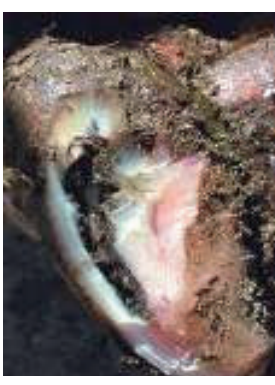

Figure 5.

White line separation the manufacturers manual. The sensitivity of the methods for $\mathrm{Hp}$ and SAA were $0,05 \mathrm{mg} / \mathrm{ml}$ and $0,3 \mu \mathrm{g} / \mathrm{ml}$, respectively.

Collected data was transferred and organized in a Microsoft Excel 2000 worksheet and analyzed by SAS software (Statistical Analyses System) version 9, using generalized Least Square Model (GLSM) (33). Descriptive statistical analysis, calculating mean values $(\mathrm{x})$ and standard deviation (SD) / standard error of mean (SEM) were performed for all examined group of parameters.

All factors were analyzed for statistical significance using the test of least significant deviation (LSD). Standard F-test was used for analysis of differences between the groups at $\mathrm{p}<0,05$ or $\mathrm{p}<0,01$ level.

\section{RESULTS}

The concentrations of $\mathrm{Hp}$ and SAA were investigated in a group of clinically sound animals and in animals with various claw diseases. The changes in the values of Hp and SAA between the control and experimental groups were analyzed and presented in Tables 1 and 2.

\section{DISCUSSION}

Acute phase proteins (APP) in the last few decades have been well studied and applied in human medicine, but they are less investigated as a diagnostic tool in veterinary medicine, especially in farm animals. Hp and SAA proteins are considered as the most important acute phase proteins in cattle, the concentrations of which markedly increase 10100 times during subclinical or clinical mastitis, endometritis, gastrointestinal diseases, respiratory infections, starvations, numerous physical conditions, stress, long transport or trauma (21, 22), but they are absent or present in insignificant concentrations in healthy animals (23).

Laminitis and other lameness related lesions (sole ulcer, white line disease, digital dermatitis) are the most investigated claw diseases in dairy

Table 1. Calculated values of serum Hp in the experimental and control groups

\begin{tabular}{ccccccc}
\hline & Control group & HE & AL & SU & DD & WLS \\
\hline Mean & 0,22 & $0,29^{\mathrm{a}}$ & $0,59^{* * \mathrm{~b}}$ & $0,59^{* * \mathrm{~b}}$ & $0,37^{* * \mathrm{~b}}$ & $0,25^{\mathrm{a}}$ \\
SEM & 0,01 & 0,02 & 0,10 & 0,08 & 0,03 & 0,03 \\
\hline
\end{tabular}

* - statistical difference between values of the control and the experimental groups at level $p<0.01$

Values with the different superscript differed significantly $(\mathrm{p}<0.05)(\mathrm{a}, \mathrm{b})$

Table 2. Calculated values of serum SAA in the experimental and control groups

\begin{tabular}{ccccccc}
\hline & Control group & HE & AL & SU & DD & WLS \\
\hline Mean & 111,35 & $195,28^{\mathrm{a}}$ & $442,76^{* * \mathrm{~b}}$ & $590,00^{* * \mathrm{~b}}$ & $281,26^{* * \mathrm{~b}}$ & $95,6^{\mathrm{a}}$ \\
SEM & 9,51 & 8,95 & 76,98 & 52,39 & 29,44 & 13,61 \\
\hline
\end{tabular}

** - statistical difference between values of the control and the experimental groups at level $\mathrm{p}<0.05$

Values with the different superscript differed significantly $(p<0.05)(a, b)$ 
cows $(24,29,30)$. The prevalence of lameness in dairy cows usually varies from 1-21 \% $(25,26)$ with several variations in different studies, where a relatively high percent of lameness is reported between the farms at 2-54\% (25) and 6-42\% (27). Floor slipperiness and cow care quality are usually two factors that show significant correlation with lameness (27). This study corresponds with previous reported investigations $(20,28,31)$ and indicates that various claw diseases may induce a systemic reaction and increased production of some acute phase proteins.

Significantly higher concentrations of haptoglobin and serum amyloid A protein were found in groups with acute laminitis and sole ulcer compared with healthy animals. Acute laminitis, sole ulcer and digital dermatitis induced significantly higher levels of Haptoglobin $(0,59 \pm 0,10 ; 0,59 \pm 0,08$ and $0,37 \pm 0,03$ respectively) than the controls, as well as the heel erosions and the white line disease. High statistical differences were found between the experimental groups 2, 3 and 4 compared to the control group $(p<0,01)$. However, no statistical difference was recorded between the animals from the control groups and animals with heel erosions and white line separation.

Laminitis as an aseptic inflammation of the laminar corium of the claw is characterized by a different etiology and it can be considered as a predisposing factor for other claw diseases. Elevated levels of serum haptoglobin, regardless of the claw disorders, have been reported in the study of Smith et al. (31) at first testing, which considerably decrease after antibiotic treatment and corrective trimming in cattle with pododermatits septic and interdigital necrobacilosis, except in cows with pododermatitis circumscripta. Despite the fact that the mean concentration of haptoglobin in the control group showed higher values $(0,22 \mathrm{mg} / \mathrm{ml})$ than those given by the manufacturer, the results of several authors (32) enables us to use them as a referent values.

The highest serum concentrations of haptoglobin were found in animals with acute laminitis and sole ulcer $(1,53 \mathrm{mg} / \mathrm{ml}$ and $1,01 \mathrm{mg} / \mathrm{ml})$ and were approximately 4-5 times higher than the maximal concentration in the control group. Insignificant differences were recorded in groups with white line separation and heel erosion compared with the control group, probably due to the nature of the pathological process without additional complications in the deepest layers. The severity of disease and the time of exposure may be the reasons for different acute phase responses between the experimental groups which corresponds with those presented by Smith et al. (31).

Significant differences between the control and experimental groups were also observed in the serum concentration of SAA, with wider range of individual values in the experimental groups (from 60,5-935,00 $\mu \mathrm{g} / \mathrm{ml})$. Acute laminitis, sole ulcer and digital dermatitis induced significantly higher levels of SAA $(442,76 \pm 76,98 ; 590,00 \pm 52,39$ and $281,26 \pm 29,44 \mu \mathrm{g} / \mathrm{ml}$ respectively) than the control group, heel erosions and the white line separation. Significant levels in the SAA response were also detected between these three groups $(p<0,05)$.

Despite the higher mean concentration of serum amyloid A protein in heifers and lame cows with claw disease (sole ulcer and white line disease) compared with healthy animals, no significant difference of serum concentration of Hp between healthy and lame cows have been recorded (20, 24). In our study, significantly higher mean concentrations of SAA were measured in groups with acute laminitis and sole ulcer $(442,76 \mu \mathrm{g} / \mathrm{ml}$ and $590,00 \mu \mathrm{g} / \mathrm{ml})$. Sole ulcer, compared with other claw lesions has the strongest association with lameness and great influence on milk production, whereas prevalence of white line disease has become more common in loose-housing system and the need of claw trimming is growing (24). Significantly high difference of serum amyloid A protein was recorded in the group with digital dermatitis compared with the healthy animals and the group of white line separation (2-3 times higher concentration). Digital dermatitis as a disease of local character induces a strong acute phase response by increasing the concentrations of $\mathrm{Hp}$ and SAA. Heel erosions and white line separation showed non-significant differences compared with the control group. These findings were expected as a result of superficial lesions localized on the outer layer of the claw wall with absence of lameness.

Despite the significant rise of the concentrations of acute phase proteins in animals with claw diseases in our study, it must be emphasized that many factors beside claw diseases are influencing the organism's reaction to inflammation and infection. Having in mind that in most cases claw diseases can be found at the same time with concurrent unrelated pathological processes, the finding of increased APP could not be used as a sole method for diagnosis, but as an additional tool beside the clinical examination. Further investigation needs to be done to differentiate whether the increase of APP will be higher in animals with claw diseases and concurrent pathological processes. 


\section{CONCLUSION}

In conclusion, the results of our investigation showed that Haptoglobin and Serum Amyloid A protein can be used as a reliable diagnostic aid for claw diseases of different etiology. Acute laminitis, sole ulcer and digital dermatitis induce an acute phase response, releasing significantly higher levels of haptoglobin and SAA in the circulation. Heel erosions and white line disease in the primary stage (without secondary infections) did not induce a significant increase of acute phase proteins. Variable differences were found in the responses to aseptic disease (laminitis), combined diseases (sole ulcer) and pure infectious disease (digital dermatitis). Larger scale investigation is needed to attempt differentiation in the acute phase response between acute, subacute and chronic laminitis, as well as in animals with concurrent diseases.

\section{CONFLICT OF INTEREST}

The authors declared that they have no potential conflict of interest with respect to the authorship and/or publication of this article.

\section{ACKNOWLEDGEMENTS}

The authors would like to thank the colleagues from Dairy farms ZK Pelagonija, Radobor and Porodin for their help in conducting this research.

\section{REFERENCES}

1. Whay, H.R., Main, D.C.J., Green, L.E., Webster, A.J.F. (2002). Farmer perception of lameness prevalence. Proc. 12th International Symposium on Lameness in Ruminants, (pp. 355 - 358), Orlando, Florida

2. Radeski, M., Janevski, A., Ilieski, V. (2015). Screening of selected indicators of dairy cattle welfare in Macedonia. Mac Vet Rev. 38 (1): 43-51. https://doi.org/10.14432/j.macvetrev.2014.11.031

3. Garbarino, E. (2004). Efect of lameness on ovarian activity in post-partum holstein cows. Thesis, University of Florida, Gainesville, Florida

4. Weaver, D.A., Jean, S.G., Steiner, A. (2005). Lameness. In: (2nd. ed.), Bovine surgery and lameness (pp. 198-258). Blackwell Publishing https://doi.org/10.1002/9780470751138.ch7
5. Green, L.E., Hedges, V.J., Schukken, Y.H., Blowey, R.W., Packington, A.J. (2002). The impact of clinical lameness on the milk yield of dairy cows. J Dairy Sci. 58, 2250-2256. https://doi.org/10.3168/jds.S0022-0302(02)74304-X

6. Murray, R.D., Downham D.Y., Clarkson M. J., Faull, W.B., Hughes, J.W., et al. (1996). Epidemiology of lameness in dairy cattle: Description and analysis of foot lesions. Vet Rec. 138, 586-591.

https://doi.org/10.1136/vr.138.24.586

PMid:8799985

7. Greenough, P. R., Maccallum, F. J., Weaver, A.D. (1981). Lameness in cattle. (2nd ed.), Bristol: John Wright \& Sons Ltd.

PMCid:PMC327455

8. Shearer, J.K., Bray, D.R., Uphrey, J.E., Elliot, J.B. (1996). Factors influencing the incidence of lameness in dairy cattle. Proceedings of the 33rd Annual Florida Dairy Conference. (pp. 40-51), Gainesville, Florida, USA

9. Bergsten, C., Hancock, D.D., Gay, J.M., Gay, C.C., Fox, L.K. (1998). Claw diseases: the most common cause of dairy lameness diagnosis, frequencies and risk groups in a University herd. Proceedings of the 31st Annual Convention of the American Association of Bovine Practitioners, 24-26 September, (pp. 188194), Spokane, Washington, USA

10. Dinarello, C.A. (1984). Interleukin-1 and the pathogenesis of the acute-phase response. N Engl J Med. 311, 1413-1418.

https://doi.org/10.1056/NEJM198411293112205 PMid:6208485

11. Bauman, H., Gauldie, J. (1994). The acute phase response. Immunol Today. 15, 74-80. https://doi.org/10.1016/0167-5699(94)90137-6

12. Standyk, A.W., Gauldie, J. (1991). The acute phase protein response during parasitic infection. Parasitol Today. 7, 7-12. https://doi.org/10.1016/0169-4758(91)90021-F

13. Eckersall, P.D., Conner, J .G. (1988). Bovine and canine acute phase proteins. Vet Res Commun. 12, 169-178.

https://doi.org/10.1007/BF00362798

PMid:2460991

14. Murata, H., Shimada, N., Yoshioka, M. (2004). Current research on acute phase proteins in veterinary diagnosis: an overview. Vet J. 168, 24-40. https://doi.org/10.1016/S1090-0233(03)00119-9

15. Gruys, E., Van Edern, M., Alsemgeest, S.P.M., Kalsbeek, H. C., Wensing, T. (1993). Acute phase proteins values in blood of cattle as indicator of animals with pathological processes. Arhiv fur Lebensmittlehygene 44, 107-111. 
16. Kushner, I. (1982). The phenomenon of acute phase response. Ann NY Acad Sci. 389, 39-48. https://doi.org/10.1111/j.1749-6632.1982.tb22124.x PMid:7046585

17. Cho, J.G. (2002). Acute phase proteins in dairy cows with mastitis. Korean J Vet Sci. 25(4): 377-384.

18. Hirvonen, J., Pyöräla, S. (1998). Acute-phase response in dairy cows with surgically-treated abdominal disorders. Vet J. 155, 53-61. https://doi.org/10.1016/S1090-0233(98)80036-1

19. Horadagoda, N.U., Knox, K.M.G., Gibbs, H.A., Reid, S.W.J, Horadagoda, A.S.E., et al. (1999). Acute phase proteins in cattle: discrimination between acute and chronic inflammation. Vet Rec. 144(16): 437-441.

https://doi.org/10.1136/vr.144.16.437

PMid:10343375

20. Thotova, C., Nagy, O., Seidel, H., Paulikova, I., Kovac, G. (2011). The influence of claw diseases on the concentrations of some acute phase proteins and other variables of the protein profile in heifers. Acta Vet. 61 (2-3): 141-150. https://doi.org/10.2298/AVB1103141T

21. Uchida, E., Katoh, N., Takahashi, K. (1993). Appearance of haptoglobin in serum from cows at parturition. J Vet Med Sci. 55, 893-894.

https://doi.org/10.1292/jvms.55.893

PMid: 8286556

22. Hirvonen, J. (2000). Hirvonen's thesis on acute phase response in dairy cattle.[Internet]. Academic dissertation, Faculty of veterinary medicine, University of Helsinki.

https://helda.helsinki.fi/bitstream/handle/1975/55/ acutepha.pdf? sequence $=2 \&$ isAllowed $=\mathrm{y}$

23. Conner, J.G., Eckersall, P. D., Wiseman, A., Aitchison, T.C., Douglas, T.A. (1998). Bovine acute phase response following turpentine injection. Res Vet Sci. 44, 82-88. https://doi.org/10.1016/0034-5288(88)90018-5

24. Kujala, M. (2010). Laminitis - related lesions and lameness detection in dairy cattle in Finland. [Internet]. Academic dissertation, Faculty of veterinary medicine, University of Helsinki, Finland https://helda.helsinki.fi/bitstream/handle/ 10138/18997/laminiti.pdf?sequence=2
25. Clarkson, M. J., Faull, B., Hughes, J. W., Manson, F.J., Merritt, J.B., Murray, J.E., et al. (1996). Incidence and prevalence of lameness in dairy cattle. Vet Rec. 138(23): 563-567.

https://doi.org/10.1136/vr.138.23.563

PMid:8795183

26. Manske, T. (2002). Claw lesions and lameness in Swedish dairy cattle: Prevalence, risk factors, effects of claw trimming and consequences for productivity. Academic dissertation, Swedish University of Agricultural Sciences, Skara, Sweeden

27. Dembele, I., Špinka, M., Stehulova, I., Pananma, J., Firla, P. (2006). Factors contributing to the incidence and prevalence of lameness on Czech dairy farms. Chez J of Animal Sci. 51(3): 102-109.

28. Jawor, P., Steiner, S., Stefaniak, T., Baumgartner, W., Rzasa, A. (2008). Determination of selected acute phase proteins during the treatment of limb diseases in dairy cow. Vet Med Czech. 53(4): 173-183.

29. Ettema, J.F., Østergaard, S. (2006). Economic decision making on prevention and control of clinical lameness in Danish dairy herds. Livestock Science 102, 92-106. https://doi.org/10.1016/j.livprodsci.2005.11.021

30. Kossaibati, M. A., Esslemont, R. J. (1997). The cost of production diseases in dairy herds in England Vet. J. 154, 41-51.

31. Smith, B.I., Kauffold, J., Sherman, L. (2010). Serum haptoglobin concentrations in dairy cattle with lameness due to claw disorders. Vet J. 186, 162-165. https://doi.org/10.1016/j.tvj1.2009.08.012 PMid:19751983

32. Nazifi S., Rezakhani, A., Koohimoghadam, M., Ansari-Lari, M., Esmailnezhad, Z. (2008). Evaluation of serum haptoglobin in clinically healthy cattle and cattle with inflammatory disease in Shiraz, a tropical area in southern Iran. Bulg J Vet Med. 11(2): 95-101.

33. Kennedy B.W. (1989). Introduction to linear models in animal breeding. University of Guelph. Canada 